DOI: $10.1515 /$ ausal-2015-0002

\title{
Examination of the selenium content of wheat grasses produced in different soil types in Csik Basin
}

\author{
M. Tamás ${ }^{1}$ \\ e-mail: tamasmelinda@sapientia.siculorum.ro \\ J. Csapó ${ }^{1,2}$ \\ e-mail: csapojanos@sapientia.siculorum.ro, \\ csapo.janos@gmail.hu \\ ${ }^{1}$ Sapientia Hungarian University of Transylvania, \\ Faculty of Technical and Social Sciences, Department of Food Science, \\ Piaţa Libertăţi 1, 530104 Miercurea Ciuc, Romania \\ ${ }^{2}$ University of Debrecen, Faculty of Agricultural and Food Sciences \\ and Environmental Management, Institute of Food Technology, \\ H-4032 Debrecen, Böszörményi u. 138. Hungary.
}

\begin{abstract}
In the course of the research, we determined selenium and dry matter content of 35 wheat grass and 35 wheat seed samples. The selenium content of the preparation plant probes was measured by spectrofluorimetric determination $\left(\lambda_{\text {excitation }}=380 \mathrm{~nm}, \lambda_{\text {emission }}=519 \mathrm{~nm}\right)$ of the resulted piazselenol complex. It was established that between the selenium content of the wheat grass and wheat seed the correlation coefficient was 0.36 at $\mathrm{p}=0.05$ level, which indicates a medium-close correlation. Similarly, there was a medium-close correlation between the selenium content of the wheat grass calculated on dry-matter basis and total selenium content of the wheat, with a correlation coefficient of 0.40 at $\mathrm{p}=0.02$ level. Afterwards, beside the selenium content, we measured the selenomethionine content by ion-exchange chromatography and highperformance liquid chromatography, and the organic selenium content
\end{abstract}

Keywords and phrases: inorganic, organic selenium content, selenomethionine, wheat grass, wheat seed, soil types. 
was calculated. A very close correlation was established between the total selenium, selenomethionine and calculated organic selenium content of wheat (the correlation coefficients were between 0.92 and 0.99 at $\mathrm{p}=0.01$ level). The correlation between the selenomethionine content of wheat grass and wheat seed was very weak $(\mathrm{r}=0.23)$.

\section{Introduction}

In the 1930s, selenium was considered to be a toxic element, but in 1943 its essential role in the living organisms was detected as it decreased the occurrence of cancer in certain conditions (Nelson et al., 1943; Clayton and Bauman, 1949; Schwarz and Foltz, 1957).

In 1966, the discovery of the mechanism of the anticarcinogenic effect of selenium was published (Shamberger and Rudolph, 1966), but then only the total selenium content of the aliments was mentioned. Recently, due to the increasing sensitivity of the analytical instruments, the physiological importance of the selenium was revealed in details: as antioxidant, together with tocopherols, it is involved in the metabolism, it helps in the healing and even in the prevention of certain cancer diseases as well as in the preservation of cell membrane integrity. By catalysing the decomposition of peroxides, the enzyme glutathione peroxidase (GPx) protects the unsaturated lipids against oxidation in the organism, and the selenium has an important role in the regulation of the GPx (Cser and Sziklainé, 1998).

The foods produced in the European countries are highly deficient in selenium. The daily selenium intake by way of food $(0.05-0.10 \mathrm{mg})$ is insignificant (Cser and Sziklainé, 1998). The Romanian (Serdaru et al., 2003) and the Hungarian $(C o m b s, 2005)$ soils also have an extremely low selenium content; therefore, by the intake of foods of vegetal origin, the selenium demand of the organism cannot be satisfied. In the opinion of modern nutrition science, the fortification of foods with selenium is almost indispensable (Reilly, 1998).

The selenium content of plants is determined mainly by the selenium content - not the total but only the bioavailable selenium content - of the soil (Terry et al., 2000). The elemental and the selenid forms are almost unavailable by way of plants from the soil; nevertheless, the absorption of the selenite and selenate compounds is more effective. The absorption of the selenates in the human organism is almost quantitative, but before the incorporation of the selenium in the proteins the main fraction is eliminated by urine. In contrast, the selenite is absorbed only in a proportion of $50 \%$, but their incorporation is higher (Bendhal and Gammelgaard, 2004). 
In addition to the inorganic selenium compounds, seleno-amino acids or their derivatives occur in plants in significant quantities. Foods of plant origin contain selenomethionine, while foods of animal origin have selenomethionine and selenocysteine content too. The selenomethionine in plants is formed from the absorbed inorganic selenium content of the soil, and in animal organisms it is able to transform into selenocystine. In the organism, about $90 \%$ of the selenomethionine is able to convert in active form (Dumont et al., 2004). In human food, selenium occurs preponderantly as selenite and selenomethionine.

To our best knowledge, in Romania, especially in the Szekler Region, the total selenium, selenomethionine and organic selenium content in wheat and wheat seed has not been studied; so, the aim of our research was the determination of selenium, selenomethionine and organic selenium content calculated from the selenomethionine content of wheat grass and wheat grown on different soil types, as well as finding correlations between these components.

Our ultimate goal is to find out the proportion of the recommended selenium intake (necessary for the human organism) which comes from the main public nutrition product, bread, obtained from wheat flour for the population of the Szekler Region. In this research article, we present the results of the study on total selenium, selenomethionine and organic selenium content of wheat grass and wheat, as well as the correlations between these selenium forms.

\section{Materials and methods}

\subsection{Collection of the samples}

During the research, at first, we determined the dry matter contents and the selenium contents of 35 different wheat grasses and wheat seed probes, while also the dry matter contents as well as the total selenium, selenomethionine and organic selenium contents of the 44 probes. The wheat plants were collected from the soil types in conformity with Table 1 .

During sample collection, the geographic locus was marked by GPS, and we accorded attention to taking the wheat seed samples (at the beginning of harvesting) from the same place, from where the wheat grass probes had been taken in the autumn of the previous year. The plant samples were pulled out manually from the soil; the soil was washed out from the roots by flowing water. The root was cut from the rest of the plant just over $0.5 \mathrm{~cm}$ above the junction of the root-green part, and only the green part was used for the analysis. The green wheat grass was immediately transported to the laboratory and it was stored at a temperature of $\mathrm{t}=-25^{\circ} \mathrm{C}$ until the preparation for analysis. 
Table 1: The investigated soil types

\begin{tabular}{|c|c|c|c|}
\hline \multicolumn{4}{|c|}{ Soil types } \\
\hline No. & $\begin{array}{l}\text { Sign of } \\
\text { soil types }\end{array}$ & Type of soil & Soil characteristics \\
\hline 1 & ASen & $\begin{array}{l}\text { Young, immature, crude alluvial soil with- } \\
\text { out diagnostical level }\end{array}$ & \\
\hline 2 & ASen-gc & Crude alluvial soil - outwashed gluey soil & \\
\hline 3 & ASgc & $\begin{array}{l}\text { Crude alluvial soil - gluey soil - extremely } \\
\text { wet, hydromorfic soil, persistently exposed } \\
\text { to moisture }\end{array}$ & $\begin{array}{l}\text { Slightly developed soils, } \\
\text { without segmentation } \\
\text { Sandy, pebbly, glacial }\end{array}$ \\
\hline 4 & RSka & Earthy barren soil - limestone furred & deposit \\
\hline 5 & KZti & $\begin{array}{l}\text { Kastanozem soil (low organic matter pro- } \\
\text { duction, few humus) }\end{array}$ & $\begin{array}{l}\text { Chestnut-coloured } \\
\text { prairie soil variant }\end{array}$ \\
\hline 6 & $\mathrm{KZmr}$ & Maroon kastanozem soil & \\
\hline 7 & $\mathrm{CZka}_{1}-\mathrm{kz}$ & $\begin{array}{l}\text { Chernozem with limestone accumulation - } \\
\text { maroon-coloured soil }\end{array}$ & $\begin{array}{l}\text { Prairie soil, rich in } \\
\text { organic matter; their }\end{array}$ \\
\hline 8 & $\mathrm{Czka}_{2}-\mathrm{kz}$ & $\begin{array}{l}\text { Chernozem with limestone-furred surface- } \\
\text { maroon-coloured soil }\end{array}$ & $\begin{array}{l}\text { characteristic is the } \\
\text { occurrence of the }\end{array}$ \\
\hline 9 & CZti & $\begin{array}{l}\text { Typical chernozem soil (slight organic } \\
\text { residuum - Ca-rich soil-forming ground, } \\
\text { approx. } 1 \% \text { humus) }\end{array}$ & $\begin{array}{l}\text { limestone for } 30-70 \mathrm{~cm} \\
\text { deep. In the dry } \\
\text { periods, the limestone }\end{array}$ \\
\hline 10 & Czka-fru & $\begin{array}{l}\text { Carbonated chernozem soil - groundwater- } \\
\text { soaked }\end{array}$ & $\begin{array}{l}\text { peels out on the surface } \\
\text { of the soil crumbs, }\end{array}$ \\
\hline 11 & Czka-e & $\begin{array}{l}\text { Chernozem soil with limestone accumula- } \\
\text { tion eroded by erosion }\end{array}$ & $\begin{array}{l}\text { forming } \\
\text { pseudomycelium. }\end{array}$ \\
\hline
\end{tabular}

The seeds were manually (with gloved hands) rolled out from the ears, then, after the removal of the chaff and awn parts, the seeds were stored in nylon package in refrigerator at a temperature of $\mathrm{t}=+5{ }^{\circ} \mathrm{C}$ until the preparation for analysis.

\subsection{Determination of dry matter content}

In the course of the determination of dry matter content, $10 \mathrm{~g}$ of sample was weighed in a measuring vial; then the sample was dried at a temperature of $\mathrm{t}=60{ }^{\circ} \mathrm{C}$ in a drying oven until mass constancy was reached. The dried samples were left overnight in open vials, and then their weight was measured again. The air-dry samples were ground in a hammer mill to flour fineness, and the dry matter content of the resulting powder was determined in conformity with the Romanian Standard (STAS 9682-2-74) method: drying in oven at a temperature of $\mathrm{t}=105^{\circ} \mathrm{C}$ until mass constancy is reached. Then, from the determination results, the dry matter content was calculated. 
The appropriately dried and flour-fine-milled wheat grass samples were sieved with a $200 \mu \mathrm{m}$ mesh sieve and the retentate was milled repeatedly until the whole sample passed through the sieve holes.

The selenium analysis was carried out based on the samples prepared in the above-mentioned mode.

\subsection{Fluorimetric determination of selenium content, preceded by wet digestion of the samples}

The solution of the samples was obtained by wet digestion, and to the acidic solution 2,3-diaminonaphtalene (DAN) was added (Bayfield and Romalis, 1985). The obtained piazselenol-complex was determined by fluorimetry $\left(\lambda_{\text {excitation }}=\right.$ $380 \mathrm{~nm}, \lambda_{\text {emission }}=519 \mathrm{~nm}$ ).

\section{Acidic digestion with Aqua Regia}

From the pretreated sample, a 3 -g-probe was taken (measured with $\pm 1 \mathrm{mg}$ precision) in a $250 \mathrm{~cm}^{3}$ round-bottom flask with ground-glass joint, and then $0.5-1.0 \mathrm{~cm}^{3}$ distilled water was added. After the wetting of the sample, 21 $\mathrm{cm}^{3}$ hydrocloric acid $(12 \mathrm{M})$ solution was added under continuous stirring, and then $7 \mathrm{~cm}^{3}$ of nitric acid $(15.8 \mathrm{M})$ solution was added dropwise, taking care to avoid the foaming of the mixture.

The round-bottom flask was connected to a water-cooler and the cooler, in its turn (trough the ground-glass joint), was connected to an absorption vessel filled with $15 \mathrm{~cm}^{3}$ of nitric acid $(0.5 \mathrm{M})$.

Having mounted the apparatus, the sample - with the mixture containing hydrochloric and nitric acid - was allowed to rest for 16 hours, waiting for the completion of the slow oxidation process.

After 16 hours of waiting (in general, the following morning), the mixture was heated until the reflux of the condensed solvent vapour occurred, and the temperature of the system was maintained for 2 hours. The content of the absorption vessel was poured into the content of the flask, and then the vessel and the reflux cooler were both washed with a volume of $10 \mathrm{~cm}^{3}$ of nitric acid solution $(0.5 \mathrm{M})$. Subsequently, the sedimentation of the insoluble particles in the reaction vessel was allowed, and then the supernatant (with relatively low solid content) was filtered through a filter paper into a volumetric flask with $100 \mathrm{~cm}^{3}$ volume. After the whole solution had gone through the filter, the insoluble retentate on the filter was washed with a few millilitre of nitric acid solution $(0.5 \mathrm{M})$. The solution thus obtained was suitable for the determination of selenium content. 
The formation and quantitative measurement of the piazselenol-complex

To the digested sample, a volume of $5 \mathrm{~cm}^{3}$ masking solution was added and the $\mathrm{pH}$ of the resulted mixture was adjusted to the value of $\mathrm{pH}=2.0$ by addition of ammonium hydroxide solution. Hereinafter, a volume of 5 $\mathrm{cm}^{3}$ DAN-solution was added, and the mixture was left in dark for about 2 hours. After the formation of the complex, the solution was washed into a separation funnel, and then extracted with aliquots of $2 \times 5 \mathrm{~cm}^{3}$ cyclohexane with a 2-minute duration of each extraction. Finally, the resulted organic phases were unified. The organic phase and the blank probe were measured with fluorimetry within 20 minutes after the extraction $\left(\lambda_{\text {excitation }}=380 \mathrm{~nm}\right.$, $\left.\lambda_{\text {emision }}=519 \mathrm{~nm}\right)$.

\section{Calibration curve}

Volumes of $0.2,0.4,0.6,0.8$ and $1.0 \mathrm{~cm}^{3}$ selenium standard solutions were pipetted into $100-\mathrm{cm}^{3}$-volume Berzelius beakers, then the solution volumes were completed to $50 \mathrm{~cm}^{3}$ with distilled water. (Hereinafter, the same procedure is followed as in the case of the samples). In the organic phase, with the total volume of $10 \mathrm{~cm}^{3}$, the concentrations of selenium were $0.2,0.4,0.6,0.8$ and $1.0 \mu \mathrm{g} / \mathrm{cm}^{3}$, respectively.

\section{Calculation of the result}

The calibration curve is linear in the $0.2-1.0 \mu \mathrm{g} / \mathrm{cm}^{3}$ concentration domain. The selenium content of the sample is calculated with the following formula:

$$
\mathrm{C}=\frac{\text { quantity of the added sample }}{\text { quantity of the extract solvent }} \cdot \mathrm{C}_{M}
$$

Where: $C_{M}$ the measured concentration, $\mu \mathrm{g} / \mathrm{cm}^{3}$,

C the selenium content of the probe, $\mu \mathrm{g} / \mathrm{g}$.

\subsection{Determination of the selenomethionine content}

Determination of the selenomethionine with ion-exchange column chromatography (IEC) and with high-performance liquid chromatography (HPLC)

The selenomethionine content was determined with INGOS AAA (amino acid analyser) apparatus, based on the principle of ion-exchange chromatography and using the method described by Mándoki et al. (2007a, b). Parallel with the AAA measurements, the determination of the selenomethionine was performed also with HITACHI LaChrom HPLC apparatus, using precolumn derivatization with OPA-mercaptoethanol (Mándoki et al., 2008). 


\section{Statistical analysis}

For linear regression and statistical data analysis, MicroCal Origin software was used.

\section{Results and discussion}

The selenium contents of wheat grass and wheat seeds are presented in Table 2. The selenium content of the samples are given both wet-based and dry-based (100\% dry weight). The average moisture content of wheat grass is $20 \%$; the dry-based selenium content is about five times higher than the selenium content of the dry matter of the original sample (wet-based selenium content). In the case of the wheat seed samples, the differences between the two calculated values are minor, given by the low differences between the dry matter contents expressed in two modes.

First, we analysed the correlation between the total selenium content of wheat grass related to the original dry matter content and $100 \%$ dry matter. As the result of the measurement for the 35 samples, the correlation coefficient had the value of 0.92 (at the significance level of $\mathrm{P}<0.1$ ). This extremely close correlation is not surprising since we are dealing with the same data set, where the single source of error is carried by the precision of the determination of dry matter content. Secondly, the correlation between the total selenium content related to the original dry matter of the wheat grass and the total selenium content of the wheat was analysed. From the data analysis of the 35 measurements, the value of the correlation coefficient was found to be 0.36 (at the significance level of $\mathrm{P}<0.1$ ), indicating a moderately strong relationship between the selenium content related to the original dry matter of the wheat grass and the total selenium content of the wheat. The relationship between the selenium content related to the $100 \%$ dry matter of the wheat grass related to the original dry matter and the total selenium content of the wheat is also moderately strong, as the correlation coefficient was 0.40 (at the significance level of $\mathrm{P}<0.1$ ).

We found that the dry matter content of the samples varied between the values of 16.3 and $22.6 \%$. The selenium content of the original dry matter was about $7.7-25.0 \mu \mathrm{g} / \mathrm{kg}$, on average $14.76 \mu \mathrm{g} / \mathrm{kg}$. The lowest selenium content for sample P13 $(7.7 \mu \mathrm{g} / \mathrm{kg})$ and the highest for sample P3 were measured $(25.0 \mu \mathrm{g} / \mathrm{kg})$. Converting to $100 \%$ dry-matter, the highest selenium content was found to be $126.3 \mu \mathrm{g} / \mathrm{kg}$ (sample P3), while a very similar value, 122.4 $\mu \mathrm{g} / \mathrm{kg}$, was detected for sample P11 with very low dry matter content. 
Table 2: Selenium content of wheat grass and wheat seeds

\begin{tabular}{|c|c|c|c|c|c|}
\hline \multirow{3}{*}{$\begin{array}{l}\text { Code } \\
\text { of the } \\
\text { sample }\end{array}$} & \multicolumn{3}{|c|}{ Wheat grass } & \multicolumn{2}{|c|}{ Wheat seeds } \\
\hline & \multirow[b]{2}{*}{$\begin{array}{l}\text { Dry } \\
\text { matter, } \\
\%\end{array}$} & \multicolumn{2}{|c|}{ Selenium content $(\mu \mathrm{g} / \mathrm{kg})$} & \multirow[b]{2}{*}{$\begin{array}{l}\text { Dry matter } \\
\text { content, } \%\end{array}$} & \multirow[b]{2}{*}{$\begin{array}{c}\text { Se content, } \\
100 \% \text { dry matter } \\
(\mathrm{mg} / \mathrm{kg})\end{array}$} \\
\hline & & $\begin{array}{l}\text { In original } \\
\text { dry matter } \\
\text { content }\end{array}$ & $\begin{array}{l}100 \% \text { dry } \\
\text { matter }\end{array}$ & & \\
\hline $\mathrm{P} 1$ & 21.9 & 16.7 & 76.3 & 90.3 & 0.142 \\
\hline $\mathrm{P} 2$ & 18.1 & 14.0 & 77.3 & 89.9 & 0.084 \\
\hline P3 & 19.8 & 25.0 & 126.3 & 90.2 & 0.007 \\
\hline $\mathrm{P} 4$ & 19.1 & 13.0 & 68.1 & 90.4 & 0.014 \\
\hline P5 & 19.3 & 13.4 & 69.4 & 91.2 & 0.149 \\
\hline P6 & 20.0 & 12.1 & 60.5 & 90.6 & 0.115 \\
\hline $\mathrm{P} 7$ & 18.3 & 17.4 & 95.1 & 90.6 & 0.129 \\
\hline P8 & 20.2 & 15.8 & 78.2 & 90.4 & 0.142 \\
\hline P9 & 17.1 & 13.1 & 76.6 & 91.1 & 0.122 \\
\hline $\mathrm{P} 10$ & 19.3 & 14.9 & 77.2 & 90.9 & 0.014 \\
\hline P11 & 15.6 & 19.1 & 122.4 & 90.6 & 0.068 \\
\hline $\mathrm{P} 12$ & 16.3 & 17.3 & 106.1 & 90.1 & 0.021 \\
\hline P13 & 20.6 & 7.7 & 37.4 & 90.4 & 0.139 \\
\hline P14 & 20.2 & 9.7 & 48.0 & 90.9 & 0.095 \\
\hline $\mathrm{P} 15$ & 22.6 & 16.2 & 71.7 & 90.0 & 0.047 \\
\hline P16 & 22.1 & 13.3 & 60.2 & 90.1 & 0.046 \\
\hline P17 & 19.7 & 13.7 & 69.5 & 90.6 & 0.120 \\
\hline P18 & 20.4 & 19.6 & 96.1 & 90.7 & 0.184 \\
\hline P19 & 18.9 & 19.8 & 104.8 & 90.0 & 0.065 \\
\hline P20 & 18.0 & 15.3 & 85.0 & 91.2 & 0.096 \\
\hline P21 & 17.0 & 14.4 & 84.7 & 90.6 & 0.047 \\
\hline $\mathrm{P} 22$ & 19.6 & 17.8 & 90.8 & 90.8 & 0.079 \\
\hline P23 & 20.4 & 14.0 & 68.6 & 91.0 & 0.079 \\
\hline P24 & 18.9 & 9.0 & 47.6 & 90.4 & 0.063 \\
\hline P 25 & 16.8 & 17.4 & 103.6 & 90.0 & 0.055 \\
\hline P26 & 18.2 & 14.1 & 77.5 & 90.0 & 0.047 \\
\hline P27 & 15.9 & 14.3 & 89.9 & 91.0 & 0.096 \\
\hline P28 & 21.5 & 19.4 & 90.2 & 90.8 & 0.152 \\
\hline P29 & 20.9 & 23.0 & 110.0 & 90.1 & 0.104 \\
\hline P30 & 20.0 & 9.6 & 48.0 & 90.7 & 0.160 \\
\hline P31 & 16.6 & 8.7 & 52.4 & 90.0 & 0.031 \\
\hline P32 & 18.4 & 10.7 & 58.2 & 90.6 & 0.047 \\
\hline P33 & 21.0 & 11.1 & 52.9 & 90.5 & 0.037 \\
\hline P34 & 22.4 & 20.1 & 89.7 & 90.2 & 0.041 \\
\hline P35 & 17.6 & 18.4 & 104.5 & 90.0 & 0.037 \\
\hline
\end{tabular}

The lowest selenium content, $37.4 \mu \mathrm{g} / \mathrm{kg}$, was measured for sample P13 due to relatively high dry matter content $(20.6 \%)$ and very low selenium content in the original dry matter. The next lowest value, $47.6 \mu \mathrm{g} / \mathrm{kg}$, was found in sample P24, followed by $48.0 \mu \mathrm{g} / \mathrm{kg}$ (sample P30). Calculated on the $100 \%$ 
dry matter content, the studied wheat grass samples had $77.65 \mu \mathrm{g} / \mathrm{kg}$ selenium content on average.

The results of measurements on selenomethionine content of wheat grass are summarized in Table 3. The results were given related to both the original dry matter and to $100 \%$ dry matter content. Table 3 shows, however, the organic selenium content of the wheat grass (in $\mu \mathrm{g} / \mathrm{kg}$ value), expressed from the selenomethionine content related to the original dry matter and the $100 \%$ dry weight content.

The selenomethionine content of wheat grass samples related to the original dry matter content (around 20\%) was between 14 and $27 \mu \mathrm{g} / \mathrm{kg}$. The lowest selenomethionine-containing sample was sample P13 $(13.9 \mu \mathrm{g} / \mathrm{kg})$ and the highest value was measured for sample P3 $(35.5 \mu \mathrm{g} / \mathrm{kg})$. Accordingly, related to the $100 \%$ dry-weight content, the highest selenomethionine content, 178.3 $\mu \mathrm{g} / \mathrm{kg}$, was measured for sample P3 likewise, while the lowest, $67.5 \mu \mathrm{g} / \mathrm{kg}$, for sample P13. The organic selenium content of the samples related to the original dry matter contents was between 5.6 and $14.3 \mu \mathrm{g} / \mathrm{kg}$, and between 27.2 and $72.2 \mu \mathrm{g} / \mathrm{kg}$ related to $100 \%$ dry matter content.

From the data in Table 3, the correlation between the total selenium content related to the original dry matter of the wheat grass and the total selenium content of the wheat, calculated from the selenomethionine content, was analysed. From the data analysis of the 35 measurements, the value of the correlation coefficient was found to be 0.34 (at the significance level of $\mathrm{P}<0.1$ ), indicating a moderately strong relationship. Next, the correlation between the total selenium content of the wheat grass related to $100 \%$ dry-weight content and the total selenium content of the wheat was analysed. From the data analysis of the 35 measurements, the value of the correlation coefficient was found to be 0.40 (at the significance level of $\mathrm{P}<0.1$ ), indicating a moderately strong relationship.

Hereinafter, the correlation between the total selenium content of the wheat grass related to $100 \%$ dry-weight content and the selenium content of the wheat calculated from the selenomethionine content was investigated. From the data analysis of the 35 measurements, the value of the correlation coefficient was found to be 0.40 (at the significance level of $\mathrm{P}<0.1$ ), indicating likewise a moderately strong relationship.

In addition to analysing the wheat grass, the analysis of the selenomethionine contents of the supplemented number of 44 samples was carried out. The selenomethionine content of the wheat samples (reported in $\mathrm{mg} / \mathrm{kg}$ ) was summarized in Table 4, together with the selenium content of the wheat samples calculated from the selenomethionine content also reported in $\mathrm{mg} / \mathrm{kg}$. 
Table 3: Selenomethionine and organic selenium content calculated from the selenomethionine content of wheat grass

\begin{tabular}{|c|c|c|c|c|c|}
\hline Sample & $\begin{array}{c}\text { Dry } \\
\text { matter, } \\
\%\end{array}$ & $\begin{array}{c}\text { Selenomethionine } \\
\text { content in the } \\
\text { original dry } \\
\text { matter }(\mu \mathrm{g} / \mathrm{kg})\end{array}$ & $\begin{array}{c}\text { Selenomethionine } \\
\text { content in the } \\
\text { dry matter } \\
(\mu \mathrm{g} / \mathrm{kg})\end{array}$ & $\begin{array}{c}\text { Organic Se } \\
\text { content in the } \\
\text { original dry } \\
\text { matter }(\mu \mathrm{g} / \mathrm{kg})\end{array}$ & $\begin{array}{c}\text { Organic Se } \\
\text { content in the } \\
\text { dry matter } \\
(\mu \mathrm{g} / \mathrm{kg})\end{array}$ \\
\hline P1 & 21.9 & 25.8 & 117.8 & 10.4 & 47.5 \\
\hline P2 & 18.1 & 22.1 & 122.1 & 8.9 & 47.3 \\
\hline P3 & 19.8 & 35.5 & 178.3 & 14.3 & 72.2 \\
\hline P4 & 19.1 & 17.1 & 89.5 & 6.9 & 36.1 \\
\hline P5 & 19.3 & 19.9 & 103.1 & 8.0 & 41.6 \\
\hline P6 & 20.0 & 18.1 & 90.5 & 7.3 & 36.5 \\
\hline P7 & 18.3 & 24.6 & 134.4 & 9.9 & 54.1 \\
\hline P8 & 20.2 & 23.9 & 118.3 & 9.6 & 47.5 \\
\hline P9 & 17.1 & 18.9 & 110.5 & 7.6 & 44.4 \\
\hline P10 & 19.3 & 22.1 & 114.5 & 8.9 & 46.1 \\
\hline $\mathrm{P} 11$ & 15.6 & 31.3 & 200.6 & 12.6 & 80.8 \\
\hline P12 & 16.3 & 23.6 & 144.8 & 9.5 & 58.3 \\
\hline P13 & 20.6 & 13.9 & 67.5 & 5.6 & 27.2 \\
\hline P14 & 20.2 & 16.9 & 83.7 & 6.8 & 33.7 \\
\hline P15 & 22.6 & 21.6 & 95.6 & 8.7 & 38.5 \\
\hline P16 & 22.1 & 19.9 & 90.0 & 8.0 & 36.2 \\
\hline P17 & 19.7 & 21.9 & 111.2 & 8.8 & 44.7 \\
\hline P18 & 20.4 & 26.3 & 128.9 & 10.6 & 52.0 \\
\hline P19 & 18.9 & 23.9 & 126.5 & 9.6 & 50.8 \\
\hline P20 & 18.0 & 20.4 & 113.3 & 8.2 & 45.6 \\
\hline P21 & 17.0 & 20.9 & 122.9 & 8.4 & 49.4 \\
\hline P22 & 19.6 & 22.9 & 116.8 & 9.2 & 46.9 \\
\hline P23 & 20.4 & 19.6 & 96.1 & 7.9 & 38.7 \\
\hline P24 & 18.9 & 15.9 & 84.1 & 6.4 & 33.9 \\
\hline P25 & 16.8 & 23.4 & 139.3 & 9.4 & 56.0 \\
\hline P26 & 18.2 & 21.1 & 115.9 & 8.5 & 46.7 \\
\hline P27 & 15.9 & 20.6 & 129.6 & 8.3 & 52.2 \\
\hline P28 & 21.5 & 23.9 & 111.2 & 9.6 & 44.7 \\
\hline P29 & 20.9 & 27.6 & 132.1 & 11.1 & 53.1 \\
\hline P30 & 20.0 & 18.9 & 94.5 & 7.6 & 38.0 \\
\hline P31 & 16.6 & 15.7 & 94.6 & 6.3 & 38.0 \\
\hline P32 & 18.4 & 18.4 & 100.0 & 7.4 & 40.2 \\
\hline P33 & 21.0 & 16.9 & 80.5 & 6.8 & 32.4 \\
\hline P34 & 22.4 & 26.3 & 117.4 & 10.6 & 47.3 \\
\hline P35 & 17.6 & 24.4 & 138.6 & 9.8 & 55.7 \\
\hline
\end{tabular}

In the case of wheat seeds, the lowest selenomethionine content $(0.0097$ $\mathrm{mg} / \mathrm{kg}$ ) was measured for sample P43, while the highest, $0.306 \mathrm{mg} / \mathrm{kg}$, was measured for sample P30. Accordingly, the lowest organic selenium content was $0.0039 \mathrm{mg} / \mathrm{kg}$ and the highest was $0.123 \mathrm{mg} / \mathrm{kg}$.

From the data of Table 4, the correlation between the total selenium content of the wheat and the selenium content of the wheat calculated from the selenomethionine content was calculated. 
Table 4: The selenomethionine and the organic selenium content of wheat calculated from the selenomethionine content

\begin{tabular}{|c|c|c|c|}
\hline Sample & Dry matter, \% & $\begin{array}{c}\text { Selenomethionine } \\
\text { content, } \mathrm{mg} / \mathrm{kg}(3)\end{array}$ & $\begin{array}{c}\text { Organic selenium } \\
\text { content, } \mathrm{mg} / \mathrm{kg}(4)\end{array}$ \\
\hline 1. & 90.3 & 0.241 & 0.097 \\
\hline 2. & 89.9 & 0.147 & 0.059 \\
\hline 3. & 90.2 & 0.0122 & 0.0049 \\
\hline 4. & 90.4 & 0.030 & 0.012 \\
\hline 5. & 91.2 & 0.258 & 0.104 \\
\hline 6. & 90.6 & 0.221 & 0.089 \\
\hline 7. & 90.6 & 0.241 & 0.097 \\
\hline 8. & 90.4 & 0.253 & 0.102 \\
\hline 9. & 91.1 & 0.211 & 0.085 \\
\hline 10. & 90.9 & 0.0244 & 0.0098 \\
\hline 11. & 90.6 & 0.132 & 0.053 \\
\hline 12. & 90.1 & 0.042 & 0.017 \\
\hline 13. & 90.4 & 0.236 & 0.095 \\
\hline 14. & 90.9 & 0.176 & 0.071 \\
\hline 15. & 90.0 & 0.082 & 0.033 \\
\hline 16. & 90.1 & 0.092 & 0.037 \\
\hline 17. & 90.6 & 0.221 & 0.089 \\
\hline 18. & 90.7 & 0.268 & 0.108 \\
\hline 19. & 90.0 & 0.122 & 0.049 \\
\hline 20. & 91.2 & 0.181 & 0.073 \\
\hline 21. & 90.6 & 0.080 & 0.032 \\
\hline 22. & 90.8 & 0.144 & 0.058 \\
\hline 23. & 91.0 & 0.152 & 0.061 \\
\hline 24. & 90.4 & 0.122 & 0.049 \\
\hline 25. & 90.0 & 0.109 & 0.044 \\
\hline 26. & 90.0 & 0.089 & 0.036 \\
\hline 27. & 91.0 & 0.167 & 0.067 \\
\hline 28. & 90.8 & 0.276 & 0.111 \\
\hline 29. & 90.1 & 0.189 & 0.076 \\
\hline 30. & 90.7 & 0.306 & 0.123 \\
\hline 31. & 90.0 & 0.072 & 0.029 \\
\hline 32. & 90.6 & 0.082 & 0.033 \\
\hline 33. & 90.5 & 0.072 & 0.029 \\
\hline 34. & 90.0 & 0.067 & 0.027 \\
\hline 35. & 90.9 & 0.147 & 0.059 \\
\hline 36. & 90.2 & 0.236 & 0.095 \\
\hline 37. & 90.3 & 0.159 & 0.064 \\
\hline 38. & 90.5 & 0.065 & 0.026 \\
\hline 39. & 90.4 & 0.176 & 0.071 \\
\hline 40. & 91.0 & 0.114 & 0.046 \\
\hline 41. & 90.6 & 0.072 & 0.029 \\
\hline 42. & 90.4 & 0.169 & 0.068 \\
\hline 43. & 90.0 & 0.0097 & 0.0039 \\
\hline 44. & 90.5 & 0.166 & 0.067 \\
\hline
\end{tabular}

The calculus was based on the known molecular mass of the selenomethionine. From the data analysis of the 44 measurements, the value of the corre- 
lation coefficient was found to be 0.99 (at the significance level of $\mathrm{P}<0.001$ ), indicating a very strong relationship.

This very strong correlation was expectable since the selenium bounded in the selenomethionine represents an important part of the total selenium. As the wheat samples were collected in the same time (in the same developmental state), it was expectable that the correlation between the two values should be very tight. Next, the correlations between the total selenium content related to the original dry-matter of the wheat grass, the selenomethionine content of the wheat and the selenium content calculated from selenomethionine content, respectively, were investigated. From the data analysis of the 35 measurements, the value of the correlation coefficient was found to be 0.92 (at the significance level of $\mathrm{P}<0.001$ ), indicating a very strong relationship. In the case of the selenium content calculated from the selenomethionine content, for the 35 measurements, the obtained correlation coefficient was likewise 0.92 (at the significance level of $\mathrm{P}<0.1$ ), indicating a very strong correlation as well.

Hereinafter, the correlation between the total selenium content of the wheat grass related to $100 \%$ dry-weight content and the selenomethionine, respectively the selenium content of the wheat calculated from selenomethionine content was calculated. From the data analysis of the 35 measurements in the case of selenomethionine content, the value of the correlation coefficient was found to be 0.92 (at the significance level of $\mathrm{P}<0.001$ ), indicating a very strong relationship. For the selenium content of the wheat, calculated from the selenomethionine content of the 35 analysed samples, the value of the correlation coefficient was the same, 0.92 (at the significance level of $\mathrm{P}<0.001$ ).

Next, the correlation between the selenomethionine content of the wheat and the selenomethionine content of the wheat grass related to $100 \%$ dry-weight and the selenomethionine, respectively, the selenium content of the wheat related to the original dry matter content, from selenomethionine content, was investigated. From the data analysis of the 35 measurements, the value of the correlation coefficient was found to be 0.23 (at the significance level of $\mathrm{P}<0.5$ ), indicating a weak relationship. And, at last, the correlation between the selenomethionine content of the wheat and the selenomethionine content of the wheat grass related to $100 \%$ dry-weight was investigated. From the data analysis of the 35 measurements, the value of the correlation coefficient was found to be 0.27 (at the significance level of $\mathrm{P}<0.5$ ).

In Table 5, the correlations between the selenium, selenomethionine and organic selenium content calculated from the selenomethionine content of wheat and wheat grass samples are summarized. 
Table 5: Correlations between the selenium, selenomethionine and organic selenium content calculated from the selenomethionine content of wheat and wheat grass samples (The summarizing table of the correlation coefficients)

\begin{tabular}{|c|c|c|}
\hline Components & $\mathrm{P} \%$ & $\mathrm{r}$ \\
\hline $\begin{array}{l}\text { Wheat grass Se content related to original dry matter - } \\
\text { Wheat grass Se content related to } 100 \% \text { dry matter }\end{array}$ & 0.001 & 0.92 \\
\hline $\begin{array}{l}\text { Wheat grass Se content related to original dry matter - } \\
\text { Wheat Se content related to original dry matter }\end{array}$ & 0.1 & 0.36 \\
\hline $\begin{array}{l}\text { Wheat grass Se content related to } 100 \% \text { dry matter - } \\
\text { Wheat original dry matter content }\end{array}$ & 0.1 & 0.40 \\
\hline $\begin{array}{l}\text { Wheat grass Se content related to original dry matter content - } \\
\text { Wheat Se content calculated from Se-Met content }\end{array}$ & 0.1 & 0.34 \\
\hline $\begin{array}{l}\text { Wheat grass Se content related to } 100 \% \text { dry matter - } \\
\text { Wheat Se content calculated from Se-Met content }\end{array}$ & 0.05 & 0.40 \\
\hline $\begin{array}{l}\text { Wheat Se content related to original dry matter - } \\
\text { Wheat Se content calculated from Se-Met content }\end{array}$ & 0.001 & 0.99 \\
\hline $\begin{array}{l}\text { Wheat grass Se content related to original dry matter- } \\
\text { Wheat grass Se-Met-content }\end{array}$ & 0.001 & 0.92 \\
\hline $\begin{array}{l}\text { Wheat grass Se content related to original dry matter - } \\
\text { Wheat grass Se content calculated from Se-Met content }\end{array}$ & 0.001 & 0.92 \\
\hline $\begin{array}{l}\text { Wheat grass Se content related to } 100 \% \text { dry matter - } \\
\text { Wheat grass Se-Met content }\end{array}$ & 0.001 & 0.92 \\
\hline $\begin{array}{l}\text { Wheat grass Se content related to } 100 \% \text { dry matter - } \\
\text { Wheat grass Se content calculated from Se-Met content }\end{array}$ & 0.001 & 0.92 \\
\hline $\begin{array}{l}\text { Wheat Se-Met content } \\
\text { Wheat grass Se-Met content related to original dry matter }\end{array}$ & 0.5 & 0.22 \\
\hline & & \\
\hline Wheat grass Se-Met content related to $100 \%$ dry matter & 0.5 & 0.27 \\
\hline
\end{tabular}

The strongest correlation was observed between the selenium content of the wheat grass samples related to the original and to $100 \%$ dry matter content, as well as between the selenium content and the selenium content calculated from the selenomethionine content of the wheat and wheat grass samples. In these cases, the correlation coefficient values are ranged between 0.92 and 0.99 . A considerably weaker relationship between the analysed data obtained for wheat and wheat grass was observed when the values of the correlation coefficients were situated between 0.34 and 0.40 . A very loose correlation was obtained when the wheat and the wheat grass selenomethionine with the selenium (both dry- and wet-based) content was compared since the correlation coefficient was between 0.22 and 0.27 . 


\section{Acknowledgements}

We would like to express our gratitude to the employees of the Sapientia University from Miercurea Ciuc, Department of Food Science and those of the Kaposvár University, Faculty of Animal Sciences Department of Chemistry and Biochemistry, who have greatly contributed to our work; furthermore, we would like to thank the Institute of Research Programmes of Cluj-Napoca, (Contract No 209/39, 02 04, 2009) and the Domus Hungarica Programme for the financial support. Grateful acknowledgment is expressed to the heads of the TOPAS-tender (TOPAS-MANAGEMENTUL DEFICITULUI DE SELENIU DIN ROMÂNIA (PNCDI. Programul 4 - Parteneriate în domeniile prioritare. Direcţia de cercetare: BIOTEHNOLOGII. Numărul alocat la înregistrarea on-line: 1447 Contract de finanţare nr. 61-022) for financing this research.

\section{References}

[1] R. F. Bayfield, L. F. Romalis, pH Control in the fluorometric assay for selenium with 2,3-diaminonaphthalene. Analytical Biochemistry, 144. (1985) 569-576.

[2] L. Bendhal, B. Gammelgaard, Separation and identification of Se-methylseleno-galactosamine, a new metabolite in basal human urine by HPLCICP-MS and CE-nano-ESI-(MS)2. Journal of Analytical Atomic Spectrometry, 19. (2004). 950-957.

[3] C. C. Clayton, C. A. Bauman, Diet and azo dye tumors: effect of diet during a period when the dye is not fed. Cancer Research, 9. (1949). $575-580$.

[4] G. F. Combs, Importance of selenium in human nutrition. In: M. Eurola (ed.), Agrifood Research Report 69: Proceedings. Twenty Years of Selenium Fertilization, September 8-9, 2005, Helsinki, Finland, (2005) 69-108.

[5] M. Cser, I. Sziklainé László, A szelén szerepe a környezetben és az egészségvédelemben. MTA, (1998) 1-136.

[6] E. Dumont, F. Vanhaecke, R. Cornelis, Hyphenated techniques for speciation of Se in in vitro gastrointestinal digests of Saccharomyces cerevisiae. Analytical and Bioanalytical Chemistry, 379. (2004) 504-511. 
[7] Zs. Mándoki, Cs. Albert, G. Pohn, Sz. Salamon, Zs. Csapó-Kiss, J. Csapó, Separation and determination of selenoamino acids in foods and feeding stuffs by ion-exchange chromatography. Krmiva 2008. $15^{\text {th }}$ International Conference. Croatia, Opatija, 2008. June 2-5. (2008) 90.

[8] Zs. Mándoki, G. Pohn, K. Lóki, Sz. Salamon, Cs. Albert, B. Albert, Zs. Csapó-Kiss, J. Csapó, Szeleno-aminosavak meghatározása ioncserés oszlopkromatográfiával és nagyhatékonyságú folyadékkromatográfiával. $13^{\text {th }}$ International Conference of Chemistry. Cluj-Napoca (Kolozsvár), 2007. Nov. 8-11. (2007) 63-67.

[9] Zs. Mándoki, G. Pohn, K. Lóki, Cs. Albert, B. Albert, Zs. Csapó-Kiss, J. Csapó, Determination of selenoamino acids by ionexchange column chromatography and by high performance liquid chromatography. $7^{\text {th }}$ Balaton Symposium on High-Performance Separation Methods. Siófok, 2007. szept. 5-7. P-81. (2007) 139.

[10] A. Nelson, O. G. Fitzhugh, H. O. Calvery, Liver tumors following cirrhosis caused by selenium in rats. Cancer Research, 3. (1943) 230-236.

[11] C. Reilly, Selenium. A new entrant into the functional food arena. Trends in Food Science \& Technology, 9. (1998) 114-118.

[12] K. Schwarz, C. M. Foltz, Selenium as an integral part of Factor 3 against dietary necrotic liver degeneration. Journal of the American Chemical Society, 79. (1957) 3292-3293.

[13] M. Serdaru, L. Vlădescu, N. Avram, Monitoring of feeds selenium status in a southeast region of Romania, Journal of Agricultural and Food Chemistry, 51. (2003) 4727-4731.

[14] R. J. Shamberger, G. Rudolph, Protection against cocarcinogenesis by antioxidants. Experientia, 22. (1966) 116.

[15] N. Terry, A. M. Zayed, M. P. Desouza, A. S. Tarun, Selenium in higher plants. Annual Review of Plant Physiology and Plant Molecular Biology, 51. (2000) 401-432. 